\title{
CONCEPTS IN THE DEVELOPMENT OF LOCAL GOVERNMENT ADMINISTRATION IN NIGERIA
}

\author{
By C. E. EMEZI
}

In a federal political system like Nigeria, state and local governments deserve attention in and of themselves. Despite the critical domestic and international responsibilities of the federal government, state and local governments are active, vigorous and growing. Their importance in the national government rest on their continuing performance of vital public functions. This has been recognised by the Federal Military Government, and today local government in Nigeria has assumed a new national importance that supercedes what it used to be.

Constitutionally, its place has been carved out clearly in the new Constitution ${ }^{1}$, and in the deliberations of the Constituent Assembly. Structurally, it has been made the third tier of government in the federation as seen in the 1976 Local Government Decree which listed functions of national importance for local government in Nigeria. Recent Federal Government policies have also added more functions to local government and these include the administration of the ambitious federal programme on primary education (UPE) and Land Use Decree. These added responsibilities have enhanced the role of local governments in national development. It is because of these functions which local governments perform, that this paper attempts to look at some of the concepts in the growth of local government in Nigeria with a view of elucidating the changes in the concepts employed from one historic epoch to another. These concepts in conjunction can be viewed as part of the process of political development.

\section{Pre-Colonial Systems}

The development of local government in Nigeria can be looked upon as a continuous and growing process. Prior to the advent of British colonial rule, the administration of the large kingdoms of Benin and Oyo for example, centred around the Obas and the Alafin. The institution of the $\mathrm{Oba}$ is the highest and most important in Benin traditional system. The Oba of Benin before the British occupation of Benin in 1897, was a sovereign monarch of the Benin Empire on whom the political, religious, economic, ritual and social obligations revol$\mathrm{ved}^{2}$. One of the most effective political and administrative instruments of government devised by the Oba of Benin was the appointment of chiefs and people to specific titles. Rulemaking as an aspect of governmental functions was carried out by the Oba's Council the Uzama, which consisted of titled chiefs. Part of the role played by the titled chiefs was the administration of the kingdom. The day-to-day administration of the empire was carried out by the various categories of chiefs and the dignitaries of the Otu or Palace Organizations

I am indebted to Professor D. I. Nwoga of the University of Nigeria, Nsukka, and Professor B. I. Obichere of the University of California, Los Angeles for their reading of the manuscript and their valuable suggestions.

1 See the Constitution of the Federal Republic of Nigeria Part II (Federal Ministry of Information Printing Division Lagos 1979).

2 R. U. Iredia "The Oba in the Traditional Benin Political System"' (Unpublished B. A. Thesis, University of Nigeria Nsukka 1973). See also J. U. Eghareuba: A Short History of Benin (Ibadan University Press 1968). 
namely the Iwebo, the Iwegue and the Ibiwe. The Uzama nobles were members of the central government and the Eghaeubo group, functioned in the administration of the city and the provinces.

The kingdom for purposes of local administration was divided into units which generally corresponded with the local territorial grouping of a chiefdom, village group, village, ward or any collection of these. Every unit was under the control of a titled chief in Benin City. These were the holders of Eghaeubo titles. They acted as intermediaries between the Oba of Benin and the unit or village concerned. They had the responsibility of transmitting the Oba's orders to the people and also of bringing the wishes of the people to the attention of the Oba. The Oba's agents of local administration were not usually natives of the districts over which they were made to administer, for the Oba could not risk the appointment of a local head who would organise a revolt against the central government.

The village was the unit of local government and the central government agents or representatives used the village councils for the disseminationen of information from the central governments. The village was also the unit of taxation and tribute collection and the recruitment of local militia. The Oba was the focus of political authority and the concept of administration at this period was the glorification of the $\mathrm{Oba}$ and the perpetuation of the system. Structurally, all agents of administration, especially at the rural areas were the vassals of the Obas. As mentioned above, the Alafin of Oyo had an elaborate system of central and local administration. The pivot of the central government of pre-colonial Oyo, was the Oye Mesi, the Council of State that advised and even controlled the governmental activities of the Alafin. Local administration was carried out by a hierarchy of chiefs both hereditary and appointive. Military officials such as the Bashorun, Balogun and the Akakanfo, were also given responsibilities in local government. In his important study of pre-colonial Oyo, Professor Peter Morton-Williams (1964) showed the vital role played by religious leaders, Babalawo, in local administration. Like in the Benin Kingdom the agents of administration under the Alafin had the duty to preserve the King and the State.

In pre-colonial Igbo society, local government was the most essential form of administration because of the lack of monarchical and centralized administration. The Conciliar System centred around the Oha, the members of which were clan, kindred and village heads. As was the case in Oyo and Benin, the members of the Oha were the instruments of rule-making and rule-adjudication for the community.

In pre-colonial Northern Nigeria, local government was elaborate and highly structured. The Hausas had a very well organized system of local government before the Fulani conquest at the beginning of the 19th century. After the Jihad, the Fulani rulers of Northern Nigeria adopted the Hausa system of local administration and even retained the exact titles of the various officials in local administration, including the judges, tax collectors, the police, and prison officials. Professor M. G. Smith has detailed an example of the system of local administration in pre-colonial Hausa emirate in his book - Government in Zau-Zau (1960). These pre-colonial structures of local administration were re-inforced and adapted to the needs of the colonial authorities after the British taken-over of Nigeria. With hindsight, it can be asserted that time tested pre-colonial systems of rule-making and rule-adjudication formed the basis of Indirect Rule as practised by the British in Nigeria. In a recent publication entitled Traditional Rulers and Nigeria's Development (1978), Alhaji Shehu Malami, Sarkin Sudan of Wurno has detailed the importance of traditional, central, and local government in the development of colonial and post-colonial Nigeria underscoring the role played by pre-colonial local government structures in this effort. 


\section{The Colonial System 1914-1950}

The colonial system of administration introduced in Nigeria in the early part of the century under Lord Lugard was spelt out in the Native Administration Ordinance No. 14 of $1916^{3}$. Under this form of government, the colonial administration used traditional institutions of chiefs and other traditional rulers to administer the natives under the supervision of British administrative officers. In essence, the system transformed the former kingdoms ruled by the Obas and Emirs into Native Authorities. The status of the Obas and Emirs changed from that of Divine Kings to that of Heads of Native Administration, in accordance with the principles of Indirect Rule.

The Indirect Rule system which was adopted for the whole of Nigeria was one school of thought as regards the administration of native races. The other school was the "Direct Rule" which implied the imposition of direct administration by Europeans $s^{4}$. Under this system, Chiefs were retained as figure-heads and any native legal institution had its powers curtailed or rendered ineffective. This mode of administration was thought to be neither to the benefit of the natives nor to their rulers. As it became apparent that the number of British officials available in the country were inadequate to enforce law and order, the theory of indirect rule won.

In practice, 'indirect rule' was a system of local administration where administration was effected through the administrative machinery which had been created by the natives themselves under which the chiefs, the native courts, native laws and institutions were recognized and controlled by the natives themselves. Under this system, the influence of the European official was brought to bear through the native leaders; and the native was thus assisted to develop that civilization which he himself could evolve. The natives did not infact rule as the name seems to imply. The 'rulers' were of course the European field administrators and their superiors in Lagos or elsewhere.

The concept of indirect rule as a policy for the government of local peoples, derived legitimacy from its acceptance and respect for traditional political structures, traditional rulers and processes. Lugard combined the legitimacy of the Traditional Rulers by their subjects and the structural legitimacy of the traditional institutions by the society to secure compliance to the British colonial system and in turn, ensured the legitimacy of that erstwhile political authority. Legitimacy when viewed from the perspective of a political system is "a quality endowed by the citizens which facilitates the exercise of authority"5. In the ordinary European meaning of the word, a chief represents an executive authority or the person from whom such authority derives. It was therefore expedient for the colonial administration to adopt the indirect rule principlebecause in a way, it reflected the peoples' traditional political culture more especially in the Northern provinces of Nigeria.

British Social Anthropologists in their analysis of African systems of government distinguished two polar types. The one which has been called the "Chiefly" has a structure which builds up on the model of a pyramid to a chisf the apex of the pyramid and the source of all political authority. In the other, the "chiefless", political authority remains with the people themselves organized into local groups ${ }^{6}$. Inspite of these two distinguishable patterns of government in Nigeria, indirect rule was adopted for the whole country.

\footnotetext{
3 See A. H. M. Kirk-Greene (ed.) The Principles of Native Administration in Nigeria: Selected Documents 1900-1947 (London: Oxford University Press 1965), p. 19. For a more detailed analysis of Lugard's ideas, see Dame Margery Perham: Lugard: The Years of Authority (London: Collins 1969), p. 143.

4 See C. E. Temple; Native Races and their Rulers (London: Frank Cass \& Co. Ltd., 1965), 7th edition pp. 22-7, 33-42, 54-4.

5 H. N. Nwosu: Political Authority and the Nigerian Civil Service (Fourth Dimension Book Enugu, 1977), p. 6.

6 Fortes and Evans Pritchard: African Political Systems (London: Oxford University Press 1940).
} 
However, the legitimacy of the concept of "indirect rule" as a system of local government was not generally complied with or successful throughout the country. As a system of administration, the "indirect rule" suited centralized traditional political systems and compliance to it was mostly restricted to Northern Nigeria. The principal means of rising to the top of the political hierarchy in the Emirate system of Northern Nigeria was through "patron-client relationship". The indirect rule therefore became legitimated and complied with successfully in the Northern provinces because the "emirate" system accepted the merger with them the client and the colonial authority the patron.

On the other hand, indirect rule was not legitimated in Western Nigeria because the Yorubas had strong political kingdoms whose Obas were constitutional rather than absolute rulers. The community's chiefs constituted the Obas council and it was this council which took fundamental and routine decision governing the community. The imposition of the alien system detracted from their apparently democratic pattern. This was resented and resisted. In the South-eastern part of Nigeria, the "Emirate". system could not be applied in its entirety since local leaders in the areas did not enjoy the same status and influence as in the Northern provinces. The commonest unit of social organization among the Igbos for example, is the extended family or Umunna. Several group of families constituted the Igbo village and the village in turn, constituted the political community. Several independent political communities existed in Igboland as sovereign states before the advent of the British.

The colonial geovernment having accepted the principle of "indirect rule" on amalgamation of the Northern and Southern provinces in 1914 had to establish "Native Authorities" in the South. The problem that faced the administration was the absence of powerful chiefs and strong centralized political institutions in the South. It became necessary to create and support the "Warrant Chiefs" with the Native Court System as the base of "Native Authority"'?.

The village council was replaced by the Native Council. The Native council was an artificial judicial body having no traditional sanction, but the force given it by the British administration. The face-to-face nature of the village deliberation was removed and their role was invested in the all powerful "warrant chief". The warrant chiefs were detested and the British failed to recognise the Igbo traditional political institutions through which legitimacy would have been derived. Their aversion to the "indirect rule" policy was evidenced in the "Aba Womens" Riot of 1929"8.

The European officers incharge of "native authorities" were called Field Officers as distinct from Headquarters or Secretariate staff. They were incharge of native affairs or to administer the native people while those at the headquarters communicated with Whitehall on matters of general policy as well as passing down orders to those in the field. This dicothomy of field and headquarters staff affected the conception of local government administration in Nigeria, especially in the area of ordinate and subordinate units of government.

Like all future generations of colonial administrators, the field officers' main responsibility involved the examination of complaints, petitions, judicial duties in connection with the native courts and the collection of such revenue as was necessary for the maintenance of local services and the maintenance of law and order.

Field administration slowly began to take on some significant changes as the society began to experience social, economic and political developments. The colonial administration saw the

\footnotetext{
7 See A. E. Afigbo: The WarrantChiefs (London: Longmans 1972). See also C. E. Emezi, British Administration in Owerri 1900-1933 (an Unpublished Ph. D. Thesis University of Nigeria, Nsukka, 1978).

8 See Harry A. Gailey: The Road to Aba (London: University of London Press Litd., 1971).
} 
need for the local community to be involved in government. The system of Native Administration was no longer considered suited to the needs of the time and this eventually led to the reform of the system.

\section{Local Government Administration - 1950-1966}

As the country made political progress under colonial rule, especially after World War II, there was a reorganization of the local administration system. The policy of the colonial government enunciate as far back as 1949 was for replacing the Native Administration system with a system based broadly on the English model of county councils. An official report entitled "The Colonial Empire 1939-1947", presented to Parliament in 1947, acknowledged that political progress of the (dependent) territories is dependent on the development of responsibility in local government. The report went on to say that ". . . the building up of a system of efficient and democratic local government is a cardinal feature of British policy in Africa. It is now recognised that the political progress of the territories is dependent on the development of responsibility in local government; that without sound local government, democratic political system at the centre is not possible ${ }^{9} . "$

The colonial government concern with a sound, responsible and democratic local administration was an attempt to ward off political agitation just gathering momentum for self-government. It was a diversy measure to entice the emergent Nigerian political elite, to concentrate their emergies at the local level rather than getting involved in the national struggle.

However, following on the reorganization, local government legislations patterned along the British model of county, urban and district councils were passed in Western and Eastern Nigeria in 1950. By the Eastern Region Local Government Law No. 16 of $1950^{10}$, County, and District Councils were established. The functions of the councils included maintenance of law and order and good government in their area of authority. Furthermore, they were to maintain the health, safety and well-being of all persons living within their area of authority and to make bye-laws to this effect. Similarly the Western Region Local Government Law of 1952 conferred powers on the Regional Authority i.e. Western Regional Government to establish Divisional and District Councils throughout the region.

The base of political participation at the local level was broadened by the two laws mentioned above, to include the local representatives of the people. Hitherto, it must be recalled that local government administration had been the preserve of chiefs and traditional rulers assisted by an itinerant British field officer. The broadening of the base of participation was an extention of the concept of legitimacy in terms of limited franchise through voting by show of hands. The chiefs and traditional rulers were still holding sway as chairmen of councils. The Local Government Law of Western Region of Nigeria 1952, distinguishes between "Elected" and Traditional members of councils. The traditional members were chiefs and holders of other traditional offices and were either ex-officio members of these councils or were selected to sit on them by and from amongst themselves. The President of the council was the traditional ruler of the place and where they were more than one, the office rotated amongst them.

9 Quoted from N. U. Akpan "Background to the Local Administration System in the three Eastern States of Nigeria" and V. N. Moneke's "Community Government in East Central State Nigeria: A Development Approach" in Local Government Administration (Vol. 3 No. 2, 1974, Benin City pp. 47, 3-11.

10 Eastern Region Local Government Law No. 16 of 1950 (Government Printer Enugu 1950), pp. $4-43$.

11 Western Region Local Government Law 1952 No. 1 of 1953 (Government Printer Ibadan).

12 Supplement of Western Region Gazette No. 1 Vol. 4 6th January 1955 Part B. 
The period of regional self-government saw the further reorganization of local government administration and series of laws to that effect were passed through the regions. The first of this was the passing in late 1955 of a new local government law by the Eastern Regional Government, repealing and replacing the Eastern Region Local Government Law No. 16 of 1950. Under the new Law, the powers and duties originally vested in the Regional Authority (i.e. the Governor) were transferred to the Minister who in some instances exercised these powers with the approval of the Governor-in-Council; in order words, with the Executive Council.

The intensification of local government administration and other quasi self-rule practice during the process of decolonization of the 1950-60 decade, coincided with the grooming of the emergent Nigerian political, bureaucratic and intellectual elites in the art of British parliamentarianism within the context of regionalism. Political activities and other forms of social change forced local government reforms to swing in the direction of elected representatives which was associated with young, literate and "progressive elements" and away from the "traditional elements" as equated with chiefs, elders, titled men and other persons holding offices for life. This period saw legitimacy in the extension of full franchise by popular election.

By April lst 1956, local government councils were established in every quarter of Eastern Region. They consisted of one Municipal, 17 County and 79 District Councils and many hundreds of local councils. Their functions included the maintenance of law and order. Under Section 80 of the 1955 Ordinance, functions of the councils were made permissive rather than mandatory. This meant that the Minister was given the discretion of deciding what functions any particular council shall or may perform. In order words, all councils were not required to perform the same functions or duties, but were assigned such duties as the Minister may consider appropriate. Councillors were elected and some were appointed to satisfy the need of getting men and women whose knowledge and experience or social position could be of advantage to the councils ${ }^{\mathbf{1 3}}$.

The law also made provisions for the appointment of Local Government Commissioners. The appointment of Local Government Commissioners was to provide the necessary link and control of councils by the Minister. A Finance Law was passed in the Eastern House of Assembly also in 1955 enabling the Regional Government to take over the collection of all taxes by local government councils and limiting the amount of general rates which a local authority might collect from individuals. Services undertaken by local governments bodies were financed largely with grants from the regional government.

The tight control of the councils by the Minister was brought about by the abuse of office by some councils. The elected councillors freed from traditional taboos and sanctions and not giving the same loyalty as they would do to say a cultural or tribal organization to which they belonged, marked their activities as councillors with irresponsibility, corruption and greed. As a result of this, subsequent amendments were made to the law, but basically it remained the principal local government law in Eastern Nigeria until the suspension of the Nigerian constitution in 1966 following the military take-over.

Within the same period under review (1950-60) local government administration in Northern Nigeria remained the Native Administration system, but with some modifications. It was not until after the creation of states in Nigeria in 1967, was it totally reorganized. In summary we say that the philosophy of local government administration at this period was based on two fundamental concepts; namely the acceptance of two types of governments

13 N. U. Akpan: Epitaph to Indirect Rule (London: Frank Cass \& Co. Ltd. 1967), pp. 187-190. 
within a country; one subordinate to the other, but each operating independently of the other; the second was the expectation that local communities through their local government bodies, should do a lot for themselves by way of providing services and maintaining law and order while the central government should concentrate on matters of overall rational and international import.

These ideas dominated the functioning of local government administration till Nigeria attained Independence. After achieving political independence, Nigeria like other third world countries, embarked on programmes of rapid economic and social development. The success of these programmes called for a civic consciousness. Improvements in the concept and structure of local governments were made to reflect the political and economic changes in the country. The new role assigned to the local governments were to provide effective structural links with the regional governments in their plan and programmes of sustained economic growth. The efforts of the regional governments were directed towards a more effective system of local government administration that could arouse the civic consciousness necessary for rapid economic and social development. This search was halted by the Nigerian Civil War.

\section{From The Civil War Period to 1976}

Local Government administration during the civil war featured the "sole administrators" who replaced the local councillors. The "sole administrators" especially in the West and Mid-Western States were civil servants. The "sole administrators" could not discharge their function without local aid and sometimes. used their own initiative to surround themselves with a body of advisers. This body had no statutory locus nor functions. They held their offices at the pleasure of the particular "sole administrator" who selected them. After the Agbekoya Riots in Western Region in 1968 and 1969, the Military Government of Western Region established local Advisory Councils ${ }^{14}$. The sole administratorship was legitimized by the support of force and the emergency of the period. Efforts were geared towards the mobilization of support towards the war efforts.

Post civil war Nigeria saw the emergence of new concepts of local government administration. The issue that confronted the various state governments in Nigeria especially the Eastern States at the end of the civil war, was a choice between the continuation of the experiments of the 1960's based on the British model or on a new system of effective local administration which could easily be merged with indigenous institutions.

The basic difference in principle between local government and local administration centres around the term "devolution" which implies that functions and powers can be developed from the central or regional government to the local authorities which can carry out their assignments with a degree of autonomy. This was the concept which governed local government administration throughout Nigeria before the national crisis of 1966. This pattern of local government which was based on devolution of functions and power to local authorities or county councils, caught our people unprepared for the task because of lack of experienced councillors, resources, administrative incompetence and local squabbles.

A study of the system of the local government administration in the former Eastern Region was commissioned by the Military Administrator of East Central State and the Military

14 K. Panter-Brike (ed.) Soldiers and Oil: The Political Transformation of Nigeria (London: Frank Cass and Company Ltd. 1978), Chap. 2. 
Governor of South-Eastern State. The study highlighted the following defects and weakness of the former system;

a) The structure and organization were foreign to the people and were not relevant to the mode of life, aspirations and traditional government of the people.

b) It was ineffective as a machinery for promoting economic, social and cultural development at the local level.

c) Under the system, communities felt no strong sense of belonging and self-involvement in local government.

d) Waste, irresponsibility, patronage, nepotism, bribery and mal-administration were rife, partly because of lack of self-identification with the system ${ }^{\mathbf{1 5}}$.

As a result of the report of that study, the concept that won in post civil warwas that based on a pattern of "decentralization", in which functions and powers were decentralized from the centre or headquarters. The term commonly used for this form of local government was "Development Administration". The term “development administration" used in post-civil war Nigeria embodies a concept of local government administration whose principal aims and objectives were that of involving the people of the State from the "grassroots" upwards in meaningful and productive partnership with the central government in matters of social and economic development which were close and relevant to their needs and could effectively contribute to the general development and progress of the State. It replaced the former concept of local government with its undesirable dichotomy between what were considered central and local governments - a differentiation which had resulted in the confused impression among the people that their loyalties were to be shared between the two; that the one was distant, while the other was close; the one superior, while the other was inferior ${ }^{16}$. The main thrust of development administration was to exploit and canalise all available and potential resources to meet the cardinal aims of effectual and fruitful development of the State with the confidence and involved cooperation of the people. The attraction and potency of the term "development administration" lie in the fact that it is forward-looking and is all-embracing. Within it, every form of communal efforts or self-help projects, including what in the past were normally given expression through cultural, ethnic and welfare association can find scope and pride of place. It was no longer necessary for the rural people to indulge in development or self-help projects which could lead to dissipation, duplication, confusion and contradiction of efforts. The main objective of "development administration" therefore, was the total involvement of the State at all levels in the constructive partnership of the people with the government and its agencies to bring about rapid and effective economic and social development.

The structure of "development administration" had its foundation in the village - the original and traditional seat of government of the people. This emphasis on the importance of the village and its traditional functions and powers was made clear in the South Eastern State Development Administration Edict No. 7 of 1972, the East Central State Edict No. 18 of 1971 and the Bendel State Edict No. 26 of 197417. The period of "development administration" saw legitimacy as the incorporation of traditional local communities as units of government wherein local loyalty was paramount. Emphasis on the role of chiefs and elders was as patrons of local communities for engendering the spirit of development in local areas. Unfor-

15 See Official Report 1973 quoted from N. U. Akpan, Local Government Administration op. cit., p. 47.

16 See Proceedings of the Seminar on Development Administration in South-EasternState, organized by the Department of Political Science, University of Nigeria, Nsukka and the Department of Development Administration, South Eastern State Cabinet Office Calabar, 1972.

17 See C. E. Emezi "Local Administration" in Nigeria in Maps: Eastern States (ed.) G. E. K. Ofomata (Ethiope Publishing House Benin City, 1975). 
tunately, most of the development committees established by the Development Administration edicts were unable to undertake meaningful development projects without regular government subventions and grants. Such a situation was not in keeping with the spirit of "development administration" which placed a high premium on self-help with minimum financial assistance from the government.

\section{Local Government in the Northern States}

Major changes in Local Government administration occured in the Northern States of Nigeria after 1968. Remarkable changes in the local government system of some of the states in the North were made with far-reaching implications. Some states like the then NorthCentral, Kwara, Kano and Benue/Plateau made structural and administrative changes of varying degrees of importance.

Other states like the then North-Western and North-Eastern, made administrative reforms but left the structures unaffected.

The structural changes had essentially involved the subdivision of some large local government units into smaller ones, the abolition of Provincial Administrators in some, and the replacement of the term Native Administration variously by Local Government Authority, Local Administration or Local Government Areas.

Taking the reform of local government administration of the then Benue/Plateau State for example, we find that the government undertook a number of measures aimed at reorganizing the structures, functions and membership of local administration.

In undertaking these measures, the Government's main objectives were as follows:

(i) to bring Government closer to the people

(ii) to broaden the outlook of local government by making local administration more representative and in particular by reflecting the multiple tribal structure that obtained in various parts of the state.

(iii) to make local government more responsive to public opinion

(iv) to provide the Benue/Plateau State with strong effective local government units with a bias towards development ${ }^{18}$.

It would be seen from the above, that the concept was one of democraticising local government administration in the State with a bias toward development; bringing it in line with sister states in the southern parts of the country. The government also abolished the provincial administration system, thus making it possible for local administration to deal with the State headquarters direct. The government also abolished the post of senior councillors in Local Administration where they existed in order to do away with unnecessary rivalry among councillors and any feeling of superiority which might have existed on the part of some councillors toward others. All Chiefs-in-Council were abolished and replaced with Chiefsand-Councils. This was to ensure that decisions reached by Local Administration Councils were the result of a majority opinion. This also made it impossible for any chief to act contrary to the apparent wishes of his council or of his people. As the Military Governor of the then North-Central State stated in 1970, "the objective of the reforms is not only to modernize but to further democratize the Local Government bodies by decentralizing powers where appropriate and widening the scope of representation ${ }^{19}$. In Kano and North-Central

18 Northern States of Nigeria Local Governments Year Book 1970 (Government Printer Kaduna 1970) p. 1.

19 Col. Abba Kyari - Military Governor of North-Central State, Ibid., p. 3. 
States, the membership of councils were modified to include two-third elected majority. The major concept in the reorganization of local government administration in the Northern states was towards democratization of the councils and decentralization of powers from the former powerful chiefs to the people. By this process legitimacy was being re-established through popular participation rather than heredity. It must be remembered that the indirect rule system took hold in the Northern provinces of Nigeria and over the years took deep roots inspite of some amendments. This policy of democratizing the councils was a far reaching one. Theoretically, these reforms were laudable but in practice there were so many obstacles in the way that the success of these reforms became doubtful in view of the entrenched political culture as detailed by Alhaji Shehu Malami (1978).

\section{Towards the End of the Military Rule}

As the military prepared to hand-over power to the civilians in Nigeria, it took a decision to reform the local government administration system throughout the country. It was guided in this exercise by the defects of the previous local government systems in the country. Some of these defects included corruption, excessive politicking, whittling down of their powers etc. It was the belief of the military that uniformity of institutions at the local and state levels was going to build Nigeria into a more stable political entity. In embarking on the reforms, the Federal Military Government was further motivated by the necessity to stabilise and rationalise government at the local level. This entailed the decentralization of some significant functions of State Governments to local levels in order to harness local resources for rapid development. The Federal Military Government also decided to recognise Local Government as the third tier of government activity in the nation. Local government was expected to do precisely what the word local government implies; that is - governing at the grass-roots or local level ${ }^{20}$. The reforms also intended to stimulate democratic self-government and to encourage initiative and leadership potential and enshrine the principle of political responsibility. Through these reforms, it was hoped that every stratum of the Nigerian society could benefit from the continued prosperity of the country through the availability of the basic amenities at the local level.

On the basis of the guidelines given by the Supreme Military Council, the unit of local administration in all the States of the federation was called Local Government. The ideal minimum population for a Local Government was 150,000 unless in exceptional circumstances where this figure may be slightly less. On the basis of this, the divisional structure of the state governments throughout the country were restructured into Local Government units for purposes of the reform. A total of 299 Local Governments were established throughout the country. The principal aims of these Local Governments are:

a) To make appropriate services and development activities responsive to Local wishes and initiatives by developing or delegating them to local representative bodies;

b) to facilitate the exercise of democratic self-government close to the local levels of our society, and to encourage initiative and leadership potential;

c) to mobilise human and material resources through the involvement of members of the public in their local development;

d) to provide a two-way channel of communication between local communities and government (both state and federal) ${ }^{\mathbf{2 1}}$.

20 Guidelines for Local Government Reform op. cit.

21 Ibid. p. 1. Functions which were devolved to Local Governments are stated in Parts A and B of Table 1. 
Traditional Rulers were not left out in the reorganization scheme. As was stated by the Federal Military Government "it is not the intention of Government to destroy the organic unity of the traditional chiefdoms, Emirate or similar institutions"22. In some cases large traditional authority were split into more than one Local Government. The Emirate or Traditional Council in addition to the Emir or Chief as President consists of traditional title holders and two representatives of each local government council. Where however, a Local Government is conterminous with an existing Local Government Authority with a single Emir or Paramount Chief, the Emir or Paramount Chief shall be the active President of the new Local Government Council. The functions of the Emirate Traditional Council include formulation of proposals as advice to Local Governments. Determination of customary laws and practices on all matters including that relating to land. Determination of religious matter where appropriate. Harmonization of the activities of Local Government Councils through discussion of problems affecting them generally and giving advice and guidance to them etc. ${ }^{23}$ It is worthy of note that this council will be financed by:

a) such moneys as may be supplied to the Council by the Local Government or Local Governments in its area; and

b) such moneys in the way of grants-in-aid as may be made to it by the State Government ${ }^{\mathbf{2 4}}$. It could be seen from the above, that the Traditional Council has been superceeded by the Local Government Council. The concept of local government administration of the federal military government therefore, is one of professional management of local affairs for the benefit of all the people. It is legitimized by the popular participation of the people through their elected councillors.

Despite the fact that the intention of the Federal Military Government is not to leave out the traditional rulers in practice, they are left out because of the dimunition of their traditional political and administrative powers and the newly created local government councils; which are made up of popularly elected councillors, who are not necessarily members of the traditional aristocracy.

The danger exists that these new reforms will result in the creation of a dualism and conflict in role performance, because many local people will identify and obey the traditional rulers by force of habit and political culture and neglect the directives of the local government councils as happened in the early history of British colonial administration in Nigeria. 


\section{Conclusion}

We have attempted an overview of the development of local government administration in Nigeria, highlighting the concepts associated with this growth. Prior to the advent of British colonial rule, the administration of the large kingdom of Benin for example, centred around the Oba who was represented by his vassals in the rural areas. The village was the unit of local government administration.

The colonial system of administration introduced in Nigeria adopted the concept of indirect rule as a system of administration. The basic principle underlying this system of administration was the utilization of traditional institutions of administration where they existed; and where they did not exist to create one. The system of administration saw Nigeria through four decades of colonial rule.

Changes were introduced following the end of World War II as a result of the social, economic and political advancement made throughout the country. The reforms centred around the introduction of elected local councils through limited franchise. The traditional rulers remained the chairmen of the local government councils. With the granting of internal self-governments in Nigeria which coincided with the emergence of a new elite in the society, the base of political participation at the local level was widened to include popularly elected councillors. The post-independence concept of local administration in addition to legitimizing the institution by popular election was the idea of bringing government nearer to the people. The search for a lasting formula for this was broken by the Nigerian crisis of 1966. Local government administration during the civil war was through sole-administratorship. This was an emergency attempt geared towards winning the war. As an emergency measure, it was backed by force.

Post-civil war Nigeria saw the emergence of the concept of development administration. It was legitimized by the utilization of the traditional village unit as the locus of local administration.

The military as a prelude to handing power to the civilians in Nigeria reformed local government administration by creating 299 Local Governments throughout the country. These Local Governments were made the third tier of government and have a secured placed in the new constitution. In conclusion one can say that of all the political institutions borrowed from the West, local government administration has the advantage of an extended breaking in period, and as such, it is hoped that it has come to stay. 
tries, was economically drained, its moral values were ignored by the colonial ruler, its social system including agriculture was destroyed. India entered international life, almost 100 years later than Japan, with a twofold, i.e. economic and psycho-sociological, deficit. - The Japanese epoch of seclusion was followed by a period of expansion. Japan won victories in wars with consequential gains of colonial territory and financial means as well as international political recognition and privileges. Although annoying the established world powers by "dumping" and "imitation", Japan as a single country could expand without changing the international economic frame. If India together with the other developing countries would create the same favourable international trade conditions for themselves now as Europa and Japan had at the start of their industrial development, the existing economic world system would necessarily change. - Before joining world trade under modern conditions, India would have to restore its autochthonic structure beginning with agriculture which was the given base at the start of industrialization in Europe and in Japan. Whether a period of expansion can follow like in case of Japan is doubtful.

\section{Concepts of development of local government administration in Nigeria By C. E. EMEZI}

The paper notes the importance attached to local government administration in Nigeria and briefly examines the traditional instruments of local administration in pre-colonial Nigeria. Thereafter, it attempts an overview of the concepts in the development of local government administration through four major epochs in Nigerian political history namely the colonial period, the period of decolonization, post-independence and post-civil war periods. One of the main thrust of local government reforms in Nigeria has been the swing of the pendulum from an attachment to traditional patterns of authority to a swing to elected representative councils.

The Federal Military Government, as a prelude to handing over power to civilians in Nigeria, gave the country a reformed uniform system of local government. There is the feeling that the reformed system may result in a conflict of roles between the traditional and modern instrumentalities of local government.

\section{The Israelis in Entebbe - Rescue or aggression? BY U. O. UMOZURIKE}

One hundred and five Israeli citizens in a plane hijacked to Entebbe were in great danger of losing their lives in the hands of Palestinians and their supporters. In view of President Amin's disdain for Israel, it was difficult to predict what he would have done even if Palestinian prisoners were released in exchange for the hostages. The right of a state to self-defence extends to the protection of citizens in great jeopardy in a foreign land. One prerequisite for the exercise of the right is that the imminent danger and the number of citizens must be proportional to the infringement of territorial sovereignty. Another prerequisite is that the foreign state must be either unwilling or incapable of protecting the foreigners. The principle of respect for fundamental human rights supports the right of humanitarian intervention to rescue national mortally endangered in a foreign land.

Israel was legally right to intervene an actions reasonably necessary for the exercise are justified but not actions in excess. The destruction of the radar system at Entebbe and the removal of expensive military equipments went beyond the requirements for the rescue and therefore ground liability for compensation. 